\title{
Keying In On Big Sagebrush
}

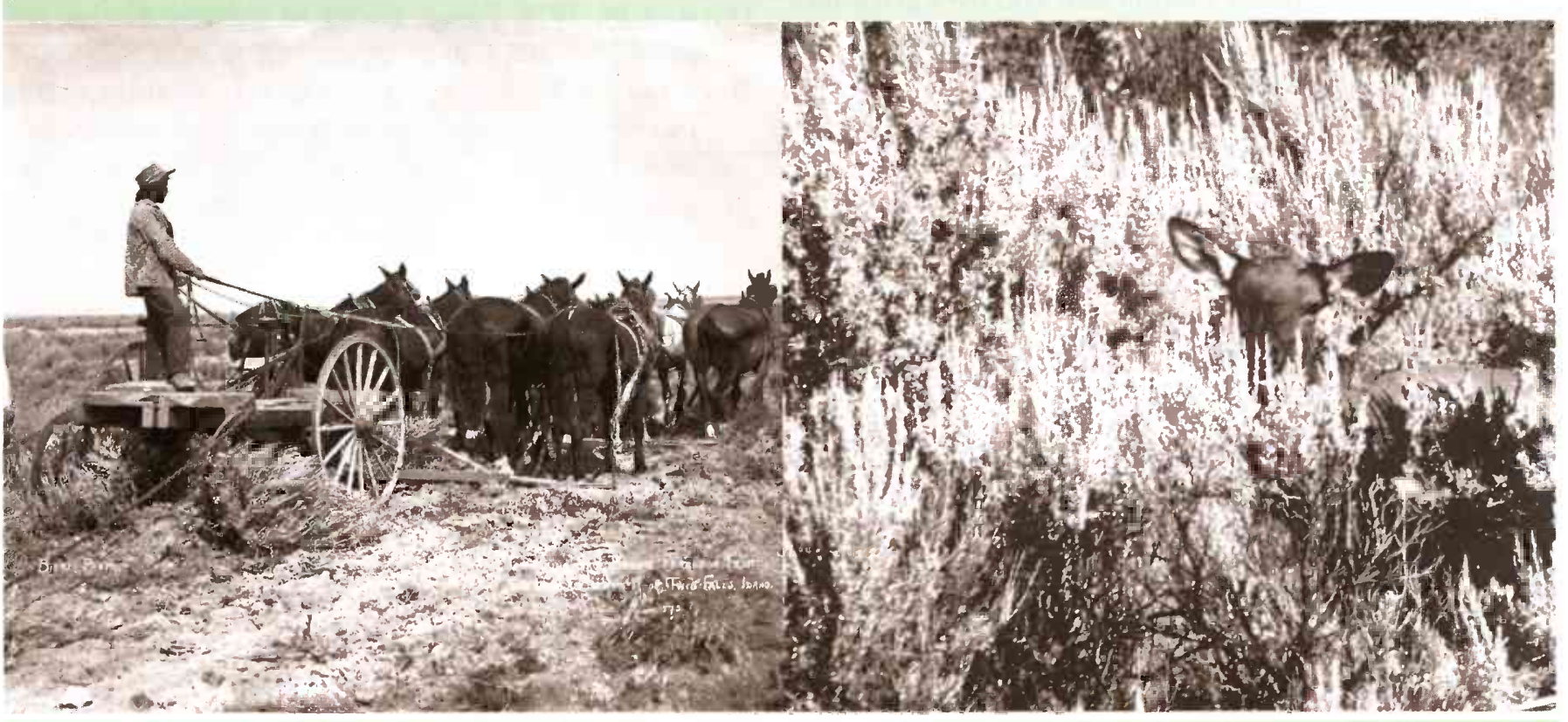

Attitudes regarding big sagebrush communities are changing from favoring their destruction to promoting their conservation. Left photo courtesy of the Twin Falls, Idaho Public Library, Bisbee Collection.

\section{A guide for identifying the four subspecies of big sagebrush.}

\author{
By Michael R. Frisina and \\ Carl L. Wambolt
}

I nterest in sagebrush plant communities has intensified due to national concern about wildlife associated with them. Sage-grouse and other native fauna closely associated with sagebrush plant communities are thought to be declining in many areas. Several range-wide petitions have been filed for listing the sage-grouse under the Endangered Species Act. The black-tailed prairie dog, often associated with sagebrush-grass types, and the sagebrush dependent pygmy rabbit are also said to be in decline.

Although the landscapes of the western United States are commonly typified by diverse sagebrush dominated floras, there is a long standing attitude in the West that takes sagebrush plant communities for granted or considers them little more than a hindrance to agricultural uses. This is especially true of big sagebrush, the most common and widely distrib- uted sage species in the western United States. Slowly this attitude is changing to one of concern for the conservation of sagebrush plant communities.

Over the years, those interested in the management of sagebrush habitats have asked us for tools they can use in the field to better identify the diverse sagebrush taxa $(4,5)$. This paper provides an aid in the form of photographs and descriptions for identifying four generally accepted subspecies of big sagebrush. We chose to discuss big sagebrush as it is the species most often at the center of controversy due to frequent proposals to kill it by burning, spraying, or plowing.

Our purpose is to aid the field investigator with identification. We also contrast the ecological characteristics of the big sagebrush subspecies. Our approach closely follows Wambolt (3), Wambolt and Frisina (4), and Wambolt and Frisina (5). 
Sagebrush taxa occur on an estimated 270 million acres in the region $(1,2)$. Many sagebrush taxa are habitat type dominants strongly associated with naive fauna. The genus (Artemisia) and species (tridentata) for big sagebrush were first described by Nuttall in 1841 based on a specimen he collected on the Snake River Plain of Idaho. Later taxonomists divided big sagebrush into the four subspecies we discuss while some recognition has been provided for even further separation within big sagebrush.

Although different subspecies of big sagebrush may occasionally be found growing together, generally they require different environmental conditions. Table 1 contrasts the environmental requirements of big sagebrush to provide insight to the ecological variation existing among the many communities occupied by big sagebrush.

\section{Basin Big Sagebrush}

It has often been stated that the land occupied by basin big sagebrush could be farmed. That is generally the case because this subspecies occupies deep well-drained soils usually found in valley bottoms or other locations where such soils occur.

\section{Mountain Big Sagebrush}

Mountain big sagebrush, like basin big sagebrush, requires more moisture than does the Wyoming subspecies. However, mountain big sagebrush usu-

\section{Ode to Sagebrush}

\section{C) R. Margaret Frisina}

your spreading branches keep grazers at bay provide sheltering nests, shade from heat of the day an evergreen nursery for young of all ilk nurturing life forms from insects to elk feed hungry wildlife in times of deep snow water the forbs that around your base grow anchor the soil so that none blows away add color and scent to the dawn of each day secret the sage-grouse and curtain their dance provide perfect cover for upland romance reminder of rangelands in wide-open days of what we will lose if we keep up our ways for despite all the good you unquestionably do we just seem intent to eradicate you in the name of improvement we burn you right out "Better habitat for wildlife," some of us tout "My cattle don't eat it," others say

"Another damn weed! It gets in my way!" but all of that argument just isn't true livestock, you see, will use sagebrush, too for food and for shelter out on the range livestock and wildlife - it isn't so strange but the once mighty Sagebrush Sea of the past is now merely a trickle, just puddles at best with the fate of sage goes our wildlife bequest the wildness that was the soul of the West

Table 1. Habitat relationships of the 4 subspecies of big sagebrush (Artemisia tridentata).

\begin{tabular}{|c|c|c|c|c|}
\hline Common Name & Basin big sagebrush & Wyoming big sagebrush & Mountain big sagebrush & Subalpine big sagebrush \\
\hline Scientific Name & A.t. tridentata & A.t. wyomingensis & A.t. vaseyana & A. t. spiciformis \\
\hline Range' $^{\prime}$ & 11 & 11 & 10 & 5 \\
\hline Soils & Deep, Well drained & $\begin{array}{c}\text { Shallow clay, Xeric, } \\
\text { Sometimes silt }\end{array}$ & Variety & Mesic \\
\hline Precipitation $^{2}$ & 1 & 1 & 2 & 2 \\
\hline $\begin{array}{l}\text { Relative browsing } \\
\text { tolerance }^{3}\end{array}$ & $\mathrm{~L}$ & $\mathrm{~L}$ & $\mathrm{~L}$ & $\mathrm{M}$ \\
\hline $\begin{array}{l}\text { Relative fire } \\
\text { tolerance }\end{array}$ & $\mathrm{L}$ & $\mathrm{L}$ & $\mathrm{L}$ & $\mathrm{M}$ \\
\hline $\begin{array}{l}\text { Height at maturity } \\
(\mathrm{dm})\end{array}$ & Large & Medium & Medium & Medium \\
\hline $\begin{array}{l}\text { Vegetative } \\
\text { reproduction }\end{array}$ & No & No & No & Yes \\
\hline
\end{tabular}




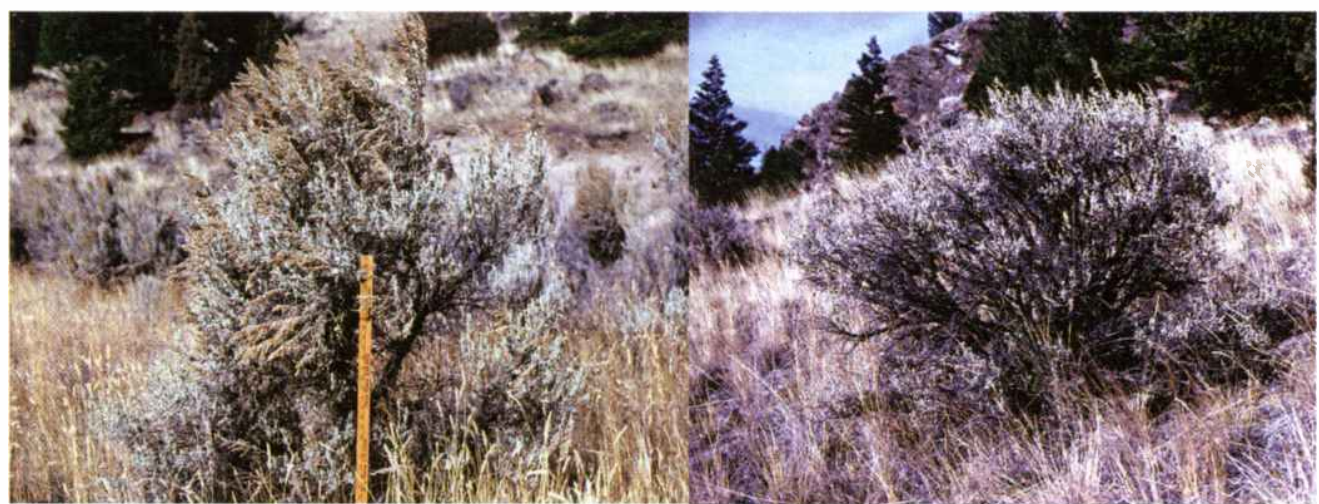

Basin big sagebrush lightly browsed on the left and heavily browsed on the right. Basin big sagebrush is a tall plant standing 1 to $3 \mathrm{~m}$ at maturity. Flowerstalks in panicle form arise throughout a relatively uneven crown.
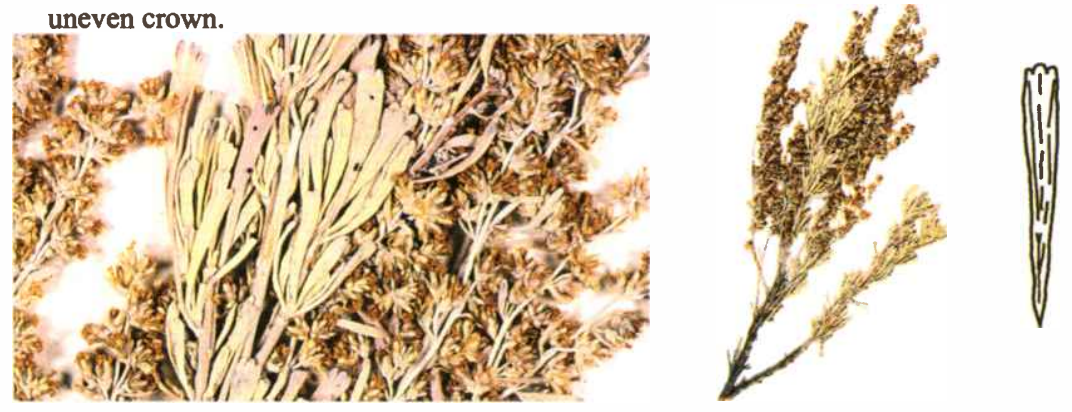

Leaves are

long in relation

to width and

wedge shaped.

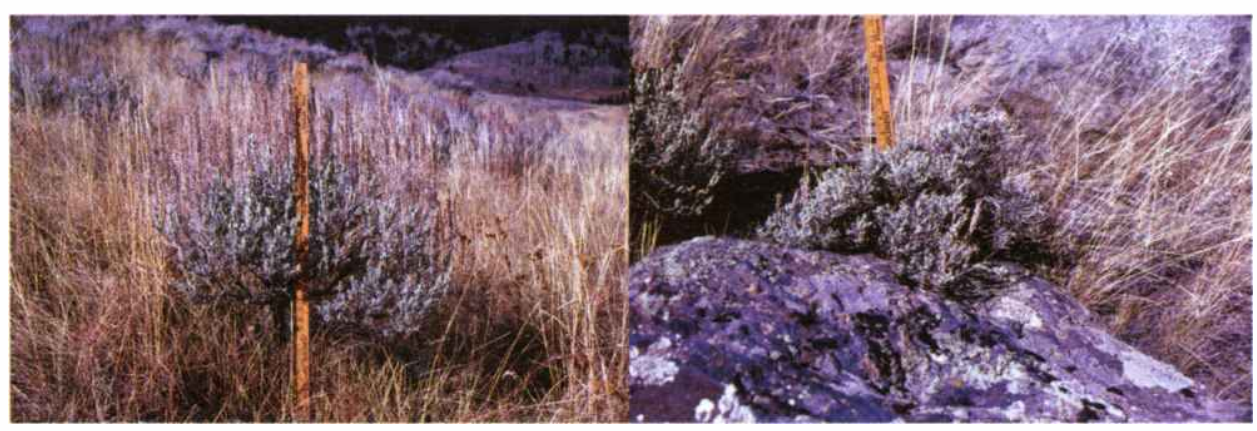

Mountain big sagebrush lightly browsed on the left and heavily browsed on the right. Mountain big sagebrush are generally less than a meter tall with flower stalks in panicles arising to nearly even lengths above foliage. Found on a variety of soils receiving precipitation levels associated with mountains and foothills.
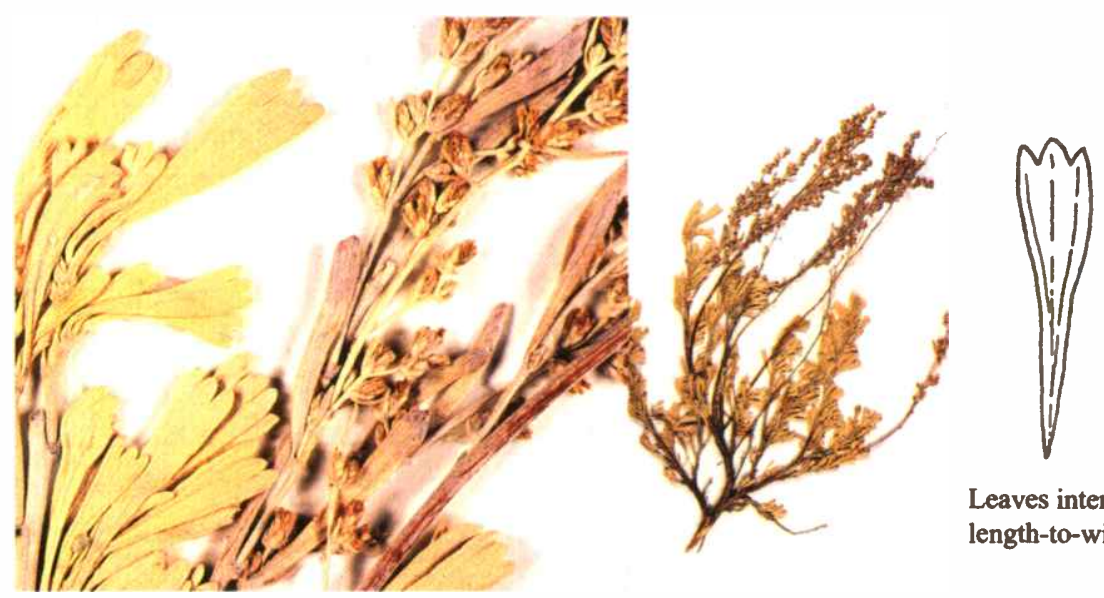

Leaves intermediate in length-to-width ratio. 


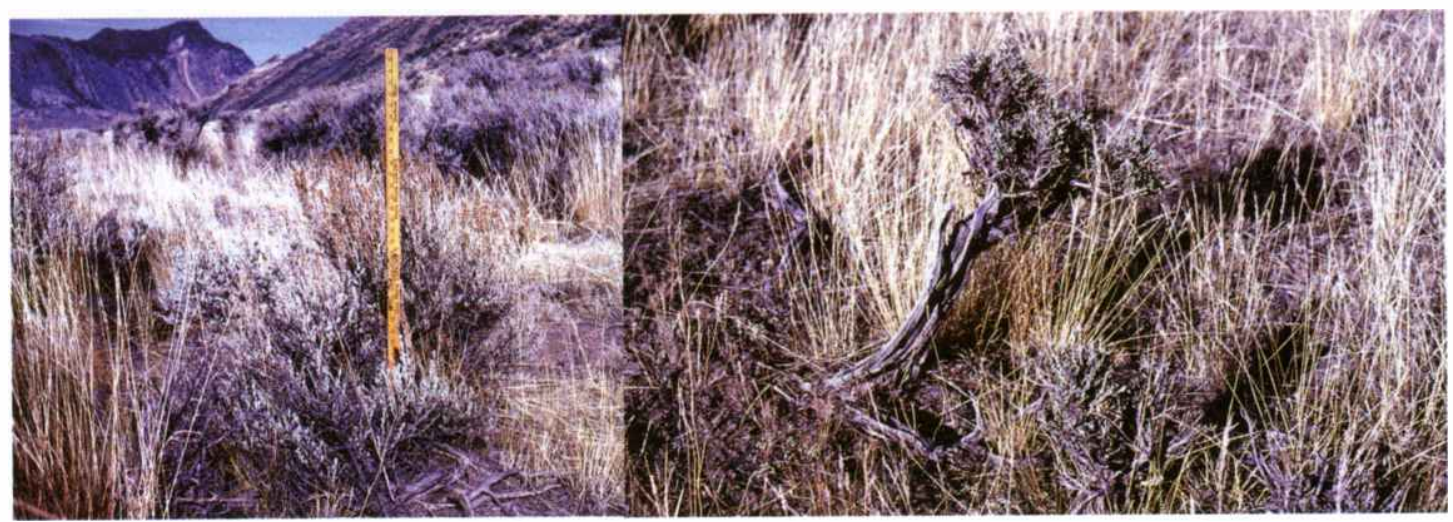

Wyoming big sagebrush lightly browsed on the left and heavily browsed on the right. Wyoming big sagebrush are generally less than a meter tall with flower stalks in a relatively compact crown.
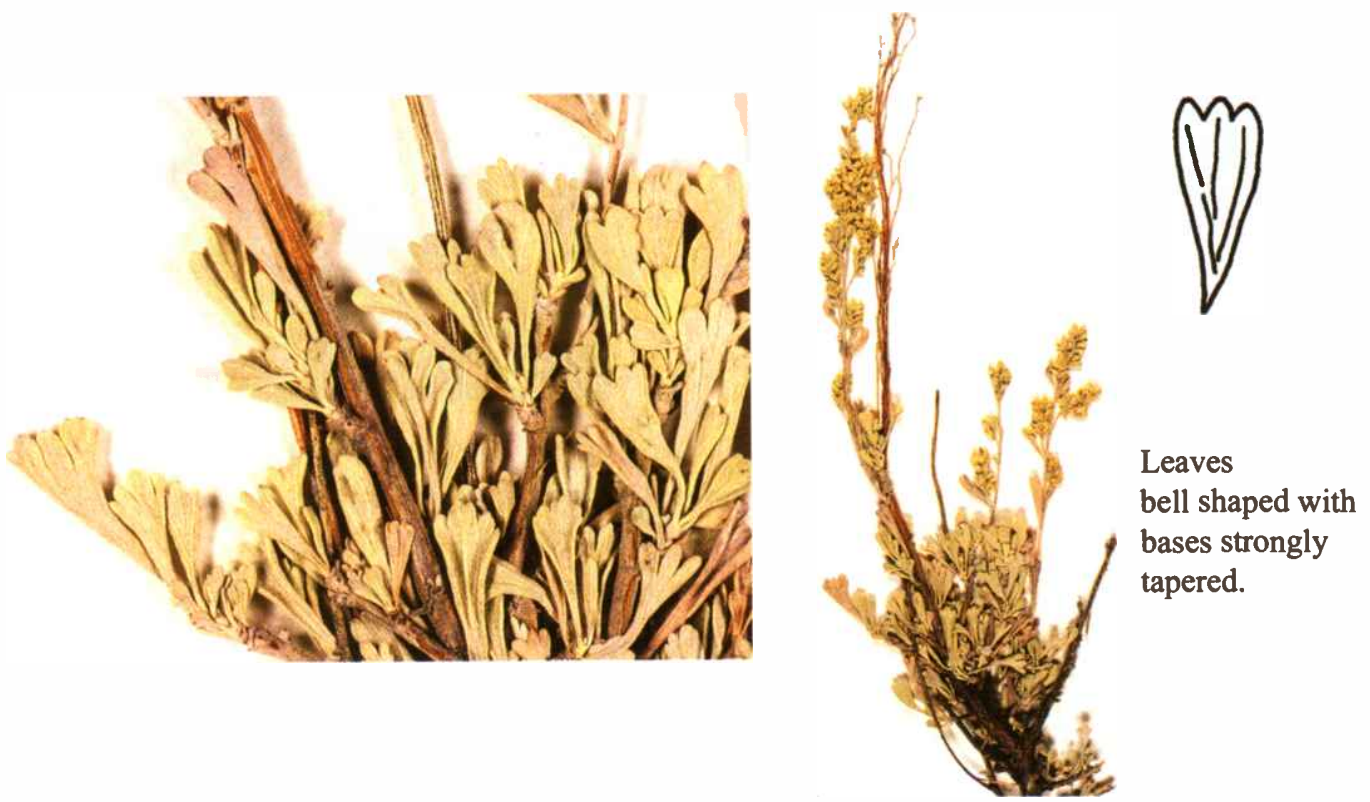

ally obtains its moisture by growing in localities with greater amounts of precipitation rather then occupying on very deep soils favored by basin big sagebrush. Soils occupied by mountain big sagebrush range from sandy through silty and clayey textures, and may often be cobbly. However, generally finer textured soils appear to be favored by the taxon. Compared to surrounding upland community types, mountain big sagebrush usually occupies the deeper more mesic locations.

\section{Wyoming Big Sagebrush}

At the other end of the habitat gradient among big sagebrush taxa, Wyoming big sagebrush occupies the most xeric locations. These sites are partially the product of shallower soils and a large amount of clay or sometimes silt in the soil profile. Wyoming big sagebrush does not do well on course-textured soils.

\section{Subalpine Big Sagebrush}

The fourth subspecies, subalpine big sagebrush, was originally considered a high elevation form of mountain big sagebrush. Subalpine big sagebrush is the only subspecies known to commonly rootsprout. Because subalpine big sagebrush generally occurs at elevations above traditional big game winter ranges, it is not usually heavily browsed. 


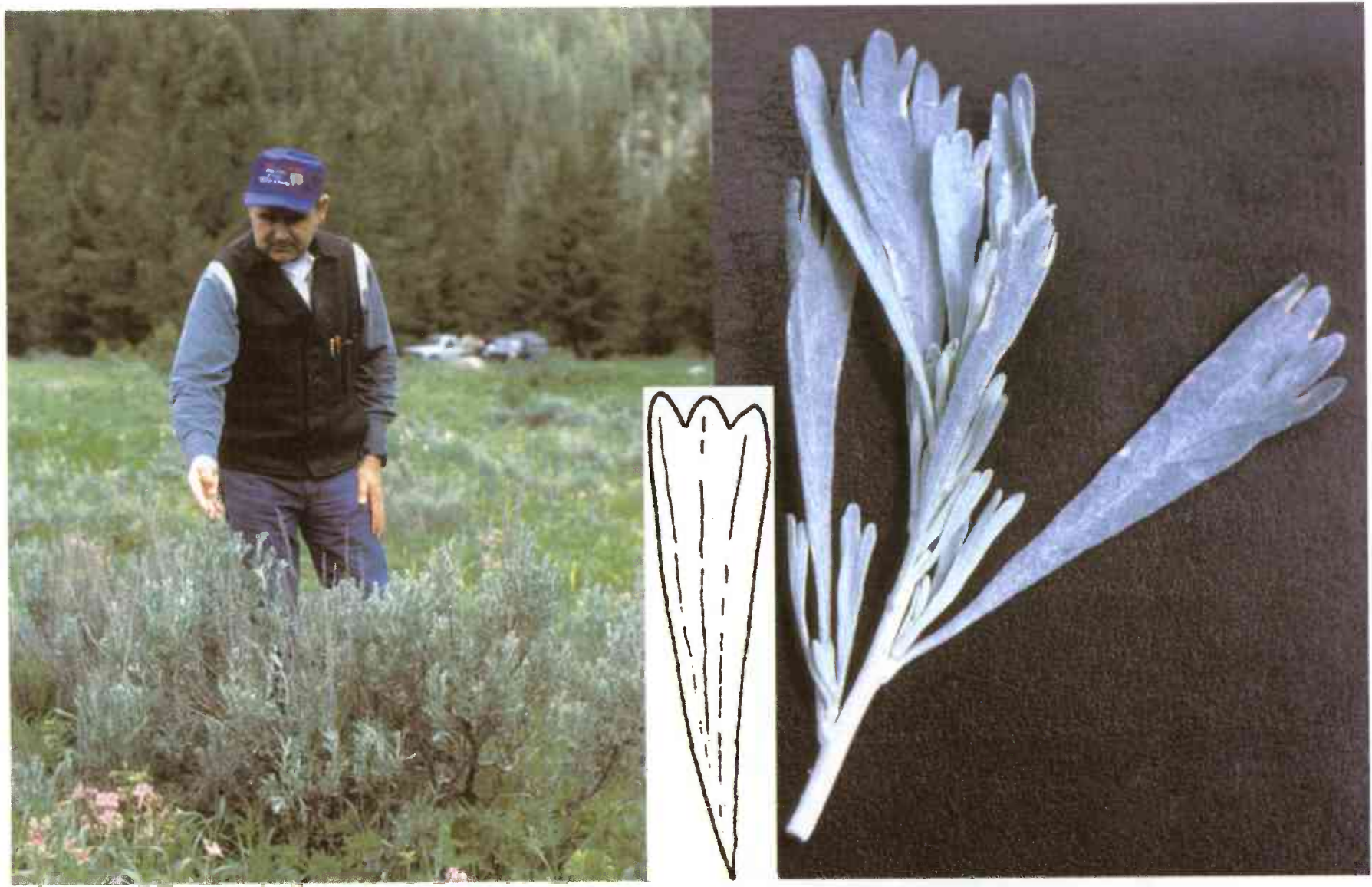

Subalpine big sagebrush usually occurs at elevations $(>2,100 \mathrm{~m})$ above most big game winter ranges and as a result is normally lightly browsed. Plants are generally less than a meter tall with large leaves and a relatively open crown.

The ability to identify the four subspecies of big sagebrush provides the land manager with insights into the ecological characteristics of the site and habitat needs of associated wildlife.

\section{Acknowledgments}

The authors thank Stephen J. Knapp and the anonymous reviewer for peer reviewing the manuscript. Montana Department of Fish, Wildlife \& Parks (Federal Aid Project W154-R-4) and Montana State University, Department of Animal and Range Sciences supported the project.

\footnotetext{
About the Authors: Michael R. Frisina is Range/Habitat Coordinator, Montana Department of Fish, Wildlife and Parks, 1330 West Gold Street, Butte, MT 59701. Carl L. Wambolt, is Professor, Department of Animal and Range Sciences, Montana State University, Bozeman, MT 59717
}

\section{References}

1. Beetle, A. A. 1960. A study of sagebrush-section Tridentatae of Artemisia. Wyo. Agr. Exp. Sta. Bull. B779. $68 \mathrm{pp}$.

2. McArthur, E. D. and A. P. Plummer. 1978. Biogeography and management of native western shrubs: a case study, section Tridentatae of Artemisia. Great Basin Naturalist Memoirs, No. 2 Brigham Young University, Provo, Utah. pp. 229-243.

3. Wambolt, C. 2001. Key to big sagebrush subspecies. pages 9-12 in Montana Sagebrush Bibliography. M. R. Frisina and J. J. McCarthy. Montana Department of Fish, Wildlife \& Parks, Helena, Montana. 60 pages.

4. Wambolt, C. L. and M. R. Frisina. 2002. Montana sagebrush guide. Montana Department of Fish, Wildlife and Parks. Helena, Montana. 71 pages.

5. Wambolt, C. L. and M. R. Frisina 2002. Montana sagebrush: a taxonomic key and habitat characteristics. Intermountain J. of Sciences. Vol. 8(2):46-59. 